\title{
ARTICLES
}

\section{Centralisation without corporatism: the politics of New Zealand business in the recession}

\author{
John Wanna*
}

New Zealand business associations have responded to adverse economic pressures through organisational centralisation, increased representational activity and by assuming a greater involvement in policy formation. Such responses from the collective organisations of business have been evident without any concomitant undertaking from business to participate in corporatist modes of policy-making. This article traces these centralist tendencies and examines the reasons for the changing forms of policy input. While some collective action theorists have contended that business organisation is incidental to the power of business, this study suggests that a revaluation of such claims is necessary. This article examines the conditions under which collective organisation of business is important.

\section{Introduction}

Business interests do not require collective organisation to exercise political and economic power (Offe, 1981; Moran, 1983; Coleman, 1988). Individual firms may join business associations but firms still retain a measure of autonomy, operate under conditions of competition, and have direct access to key decision-makers. This is seen to make business less reliant on such associations for defending their interests. In contrast, trade unions depend on internal solidarity and strong discipline to be capable of collective power (Offe, 1981). Hence, it can be argued that collectivism among business and labour interests is contingent on separate logics of collective action. Business and labour associations display very different organisational characteristics, possess different capacities to organise and have a different need for organisation. From this, Offe and Wiesenthal have concluded that collective organisation is less important for employers than for workers (Offe, 1981; Offe and Wiesenthal, 1980). 
This article suggests that under certain circumstances collective organisation is xtremely important for business. New Zealand evidence indicates that collective organisation is important for business in its relation with the state and participation in policy-making processes. This study discusses the organisational and structural characteristics of New Zealand business associations before examining in more detail their development of policy, their changing policy concerns, different patterns of access to state and recession.

\section{Existing accounts of business organisation in New Zealand}

Two different but not mutually exclusive reasons have been given for the development Tho Zealand. Some accounts stress that business of business associations in growth of trade union power. Employer associations were defensive arrangements arising out of group dynamics in reaction to the mobilisation of labour. In this pluralist view out 'cmployers for (3) (Roth, 1978, pp. 34-7). Other accounts identify the impact of government ren an immediate response to government modifications in the procedures of industria relations, making it compulsory for employers to represent their interests and negotiate through state-operated forums (Rudman, 1974, pp. 55-9). Government action throug statutory regulation both stimulated trade unions and gave rise to employer organisations.

The departure point of these interpretations assumes that employers formed lasting organisations as their representatives became increasingly embroiled in institutionalised forms of policy-making, including 'private' negotiation, arbitration and liaising with government. Both interpretations maintain that employer organisations formed in direct response to external factors. Business interests are centred at the individual enterprise level and encroachments on employer power from external influences (labour or government) and en to individual preference. They join pluralist pressure groups out of a desire to share and individual preference. The

Such historical explanations suggest that business organisation in New Zealand merged from industrial relations concerns (for similar Australian arguments see Dufty, 1984-Plowman, 1988). This presentation of the role of business associations is clear if 1 Business organisations are presented as essentially reactive and negative, only partal. Bus to labour in an conservative and plurational setting.
institution

Perhaps the main reason for this particular focus is that these explanations emerge solely from industrial relations scholars. This has restricted their study largely to employer organisations as protagonists in an industrial relations system. Other business

1 In New Zealand specific employer bodies covering industrial relations functions are reforions of employers are termed tistinguished and termed employer associations, while associations of 'trade' are further distinguished and often classified separately (for example, the Chambers of Commerce, or the Manufacturers' Federation). While the New Zealand terminology is generally consistently applied, it is, nonetheless, idiosyncratic and not consistent with the categorisations of other nations. In this paper I follow the international usage in denoting either industrial relations or trade bodies as employer associations. Where exclusive reference to trade associations is made, this is indicated. In other places, it proved necessary to distinguish between employer 'unions' and other employe organisations. groups such as trade associations are frequently marginalised, despite the fact that they often pre-date employer organisations, trade unions and arbitral legislations. As such the available literature displays less concern with the political development of organisations representing business, especially their policy-making processes and policy outcomes (an exception here from a political science viewpoint is Vowles, 1985). From an industria relations perspective, the role of business associations is often taken as unproblematic Business associations are identified simply as parties to disputes and accounts of their activities rarely go beyond such a role.

This restricted view is also held because many business associations involved in industrial relations are fictitious or 'paper' organisations, which exist to satisfy the statutory requirements of state arbitration. According to a recent industrial relations survey, pronounced levels of membership inactivity exist within these employer bodies (Brosnan, Walsh and Rowe, 1985a). This inertia among some employer 'unions', measured according to criteria such as the frequency of meetings and the consumption of services, was related exclusively to their industrial relations activities. Thus, in this sense, some business organisations can appear in name as organisational counterparts to labour unions, but not as significant political interest groups operating across a range of activities.

A more general lack of concern with the political development of business organisation has been maintained despite the substantial presence of employer and trade associations in various policy-making forums (Robinson, 1978; Vowles, 1985). For instance, in Rudman's description of the 'development and role' of employer organisations policy concerns warrant only passing mention. His account of their recent activities remains almost entirely preoccupied with reorganisational initiatives in the employers' peak body with only brief acknowledgement made of where responsibility for policymaking rests (Rudman, 1974). It appears, therefore, that apart from some schematic details relating to the organisational framework, the political character of business associations tends to be overlooked. One consequence of this for the analysis of business interest associations is that the most significant questions, such as how business associations really operate, how they arrive at policy decisions, the means and effectiveness of policy implementation and the patterns of their access or relationship to government, have been systematically neglected.

\section{The structure of business associations in New Zealand}

Two broad types of business associations have been formed to serve employer interests; associations of employers for industrial relations concerns, and trade or marketing associations for product promotion. Because of their specialist functions these two servicing types have tended to develop separately and maintain their discrete but complementary identities. ${ }^{2}$ But with the onset of the 1970-80 s recession some of these associations have begun to expand their activities from one type to the other, while merger proposals between different associational types has been an 'on-again/off-again' occurence. From a situation where specific representation was organised around functional

2 In practice this distinction is not quite as clear cut. Some specific trade associations registered themselves as industrial unions of employers to extend or complement their own trade functions. Such action was taken where trade associtions felt able to deliver own trade fuction to deliver decipe dual functional associations such as the NZ Plastics Institute (and IUOE) were generally Trades Association (and IUOE) participated in a substantial range of industrial relations activities. 
exclusiveness, greater emphasis has been placed on the development of more centralistuniversalist forms of business representation.

While their membership has increased markedly, the number of registered industrial relations employer unions has been steadily declining from 275 in 1945 to 211 in 1985 . The formation of these employer groups was sponsored by the state through the requirements of compulsory arbitration. These employer unions were registered under the Industrial Relations Act and consisted of employers related to an industry, industrial award, product, service, company or regional area. Yet unlike trade unions, the employer groups did not enjoy exclusive clientele rights to represent all related employers. Rather, they represented only their actual membership. Although the employer membership of these represented only their actual membership. Although the employer membership of these
organisations was 38,144 in 1985 (up from 16,033 in 1946), the concentration of membership was high. In 1985 only 20 unions ( 9.5 percent) had more than 500 members, but these accounted in total for 26,311 members or 69 percent of all members (Dept. of Labour, 1986, pp. 78-82). Conversely, 167 of the remaining smaller unions retained less than 100 members with most of these (130) operating with a membership of between 1 and 50 (Dept. of Labour, 1985).

Most employer unions existed in the manufacturing sector (72 with 4,035 members in 1984). But the unions with the largest memberships consisted predominantly of farmers and small-scale employers. These large membership unions were found in the industries of wholesale and retail trades, hotels and restaurants, and agriculture, grazing, forestry and fishing. Roughly half the employer unions (110) were affiliated to one of the fourteen industry associations that served as national umbrella associations combining related employer unions on an industry basis (for example, the New Zealand Federated Builders' and Contractors' Association, the Hotel Association of New Zealand, and the New Zealand Local Government Association) (Dept. of Labour, 1986, p. 75).

In addition to these unions a further series of trade associations and peak bodies existed both to coordinate employer activity while retaining functional divisions of responsibility. At the level of government-business relations involving the active participation of business associations in the policy-making process, these associations were far more significant than the separate unions or industry associations. Trade associations with fulltime secretariats and specialist officers had generally been active in promoting sectional interests of employers. Their main activities had been directed to shaping state intervention and gaining specific types of support or protection. The main national trade associations included the New Zealand Manufacturers' Federation, the Associated Chambers of Commerce, the Federated Farmers of New Zealand, the New Zealand Master Builders' Federation, the New Zealand Retailers' Federation and the New Zealand Tourist Industry Federation.

In the policy-making context, trade associations operated with largely autonomous regional branches. Hence, the Manufacturers' Federation consisted of four semiindependent regional trade associations based in Auckland, Wellington, Canterbury and the Otago-Southland region. Moreover, this Federation, formed in 1897, was also composed of some 60 separate trade groups based on specific products, production processes or market interests (NZ Manufacturers' Federation, 1985). These trade groups retained much discretionary decision-making power in relation to their specific interests. For instance, in the policy discussions over the introduction of the Goods and Services Tax in 1985 the national body and three of the trade groups each made separate submissions to government addressing their particular interests.

The main employer peak council founded in 1902, the New Zealand Employers' Federation, adopted an overarching industrial relations role, servicing small and medium employers, separate employer unions, and regional employer associations. The equivalent of the Confederation of British Industry or the Confederation of Australian Industry, this body gained its membership from employer organisations (regional associations and other national bodies) rather than individual companies (but the U.K. organisation accepts both, see Frant, 1983). The Federation initially represented 11 provincial groupings, but following the introduction of a new consititution in 1971 was restructured to consist of a Federal office resting on four self-managing regional associations (Wellington, Auckland Christchurch and Dunedin). Following two management reviews of its structure and erformance (in 1977 and 1985) the Federation a March 1986 which introduced organisational As a national organisation, the Employers' Federation, based in Went level.

closely tied to the interests of medium and small businesses. One of the majon, remained link has been maintained stemmed from the projor ways medium to medium to small businesses channelled through the regional bodies. The Federation was unded from affiliation fees levied on the four regional associations, with the Auckland association contributing by far the main part. For instance in with subscription of $\$ N Z 815,068$, the four regional associations contributed $\$ N Z 726,321$ with half of this provided by Auckland. The remaining fees were provided by General

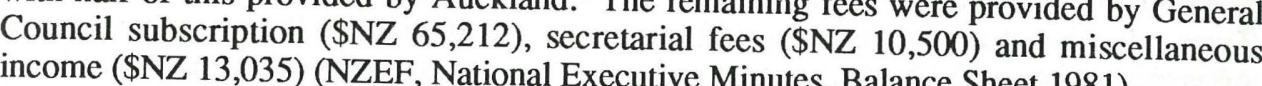
Afraid of being politically marginalised as representing Balance Sheet 1981).

Afraid of being politically marginalised as representing the smaller business sectork, the employers' peak body adopted two organisational initiatives designed to increase the voice of larger business concerns and the trade groups. In the 1970s it established two top level advisory bodies for the purposes of executive policy liaison. One of these bodies, the 'Top Tier' advisory group, established in 1977, met monthly and consisted of representatives from the major trade associations (namely, manufacturers, commerce, retailers and travel-tourism). The other consisted of 12 chief executives from big business, which met bi-monthly with the Federation's senior staff as the Prom big Advisory Group.

Out of a recognition of this divergence of interests within the Federation, the full-time leadership were reluctant to involve themselves in 'contentious issues' over policies related to business scale or conflicts between business sectors. ${ }^{3}$ As a consequence of this reluctance, and also because of the Federation's preoccupation with industrial relations servicing, the Federation had tended not to become a major policy partial relations government on wider policy matters. A previous Treasury official suggested that because of its previous inability to adequately formulate policies, and its reluctance to get involved in divisive policy formulation, the Employers' Federation had been generally 'left on the

This is a composite assessment from various sources. The Deputy Executive Director of the Employers' Federation acknowledged that the organisation 'contentious issues' relating to sectoral interests because such matters were not discuss resolved within the processes of the peak council. As a consequence, wignificle to be areas existed (for example, industry policy and protectionism) on which the Employer Federation had neither been able to formulate policy stan) policy-making process. This underdevelopment of policy dides, nor participate in the were never raised for discussion. However, it off policy did not imply that such issues role in mediating the relations between bus it second source within a regional as Federation representatives politicions representatives were slow in offering leadership, and did 'not cultivate politicians and departments sufficiently. His explanation of this was that former former chairman of the Business Roundtable argued that the other main employer 'erganisations were not represented at the 'clout level' with government, because 'employer groups were dominated by small employers and second and third level management, personnel and industrial relations people, rather than decision-makers'. Finally, a senior government official volunteered that government policy-makers found employer organisations either inept or too divided to consult on a systematic basis Involving employer representatives in particular policies did not ensure that their employer memberships would not break agreements, and accordingly governments weir frustrated because there was 'no one to talk to who could deliver'. 
outer in most government policy.' Even on economic and business-related policies the Federation (along with other interest groups) was in the main circulated with policy decisions rather than involved in their formulation (Interview, 30/1/1986). However, the Federation was a formal and at times active participant in industrial relations policy making.

Finally, perhaps the most potentially influential business group, the Business Roundtable, was established formally in 1980 as an exclusive organisation representing the chief executives of New Zealand-listed big business. An earlier Auckland-based big business 'club' with about 10 members had existed since 1976. The Roundtable formalised its existence when it required a more consistent and collective policy approach to government, when its informal nature began to reduce some of its effectiveness, and when more company executives joined placing increased administrative burden on the one or two companies servicing the group. Two influential executives (R. Trotter and H. Titter) introduced formal rules based on those of the New York Business Roundtable. After this the Roundtable elected a chairman for a two year term, with the responsibility of providing the administrative resources for the organisation.

The Roundtable's membership of 25 chief executives in January 1985 came largely from the manufacturing, oil and service industries. But a further agreement accepted at a Christchurch meeting in February 1985 extended the membership to a potential figure of 50 based on criteria of company size (a combination of local capitalisation and employment). This extension allowed executives from other industry sectors (investment, securities and finance corporations) and overseas corporations (Shell, IBM) to join. Takeovers and some resignations produced fluctuations in membership during 1985-87 but between 29 and 35 constituted the core membership. The Roundtable appointed its first full-time executive officer and lobbyist, Roger Kerr, in 1986 as further evidence of its concern to augment its influence. Recruited from government, and previously occupying the position of Assistant Secretary of Treasury, Kerr was both a useful contact or lobbyist with the new more market-oriented Lange Government, and a 'new-right' intellectual with consistent policy standpoints (NZ Listener, 6/12/86, pp. 24-5). The rightwing Centre for Independent Studies also began serving as a de facto policy think tank for this big business group.

The Business Roundtable regarded itself as a complement to other employer groups rather than in competition with them. Its official 'Statement of Purpose' stressed that it saw its role as one of longer term policy analysis and advocacy on major national issues, with an emphasis on 'a pro-active, professional and well-researched contribution to policy formation, rather than ... [the] traditional lobbying role' (NZBR, 1987 p. 15). However according to the director of the Manufacturers' Federation, the Roundtable was established primarily 'out of frustration' because big business considered 'that other employer groups were not effective' (Interview, 30/1/1986). The initial policy concerns of the Roundtable appeared to centre on off-shore investment, export strategies, power pricing, labour market flexibility, taxation policies and government economic policies.

Policy change and collective action by business; 1960s to the 1980 recession

Over the last 20 years the politics of New Zealand business has been shaped by three major influences. Significant shifts occurred in economic power due to wage bargaining (1960-70s), and after 1975 the impact of the economic recession followed by the speed and nature of economic restructuring. Second, the patterns of mediation with the state have undergone rapid change. Government policy toward the economy swung from a regulatory to a deregulatory approach, and this meant that the policy dialogue between business and the state tended to move from the level of specific concessions to general policies and policy agendas. Third, a series of internal restructurings within the representational organisations of business were implemented in order to provide greater capacity for the
leaderships of these groups to exercise a leaderships of these groups to exercise a strategic role in policy responses. These organisational moves increasingly tended to centralise the process of policy-making in
business association.

In the past the associations of business in New Zealand operated with two discrete sets
f policy responsibilities. of policy responsibilities. The Employers' Federation, its regional associations, and the
employer unions were preoccupied exclusively with industrial relations other hand, trade associations focused mainly on with industrial relations concerns. On the tariffs, importing (restrictions, licences or access) a asenting sectoral interests over trade promotion, instiances issues, industry 53-5).

This bifurcated division of policy interests was maintained because trade associations in their policy ambit by the heteriness, while the employer associations were restricted entrenched specialised trade heterogeneity of their membership and the existence of industrial relations activities for to employers associations were restricted to numerical, fin small employers, the main numerical, financial and organisational support base of the regional associations a the regional associations, relations issues. These employers vis solicy on industrial (offering advocacy or legal services) that provided somer organisations as service agencies relations direction. These were specialised functions collective protection and industrial were not often in a position to speciall or medium employers Secondly, industrial polation to develop for themselves at the firm level (Offe, 1981). significant interests which were held in common and regularly were the most economic class terms, employer associations acted to displace some of the overarching susceptabilities of capital. Moreover, this overarching industrial relations role was used to encompass both the various sectors of industry as well as the diverse sizes of business or levels of capital. In Offe and Wiesenthal's terms such employer associations conveyed the organisational 'monological' interests of business as a social group (Offe and Wiesenthal 1980).

As in Australia, the structural interests of business relating to trade and industrial relations generated a fragmented configuration of formal employer associations (Tsokhas, 1984; Plowman, 1980). On policy matters larger firms using their own company form of organisation were still able to gain access to government their own company form of business associations displayed little cohesion prior to on a one-to-one basis. But many labour organisations, business producing some strong and, business associations generally found it difficult despite producing some strong and dominating leaders to develop strong bureaucratic executives to provide a source of unity before the onset of the 1970-80s economic recession. This suggests that the heterogeneity of interests within business effectively limited its capacity role of business Similar so groups, their policy development and ad hoc interactions with the state. Similar arguments have been advanced in recent contributions to theories of collective
action (excluding those founded on game theory) (Offe and Wiesenthal, 1980). Such theories suggest that it is important to regard employer associations as specific forms of organisation contingent on structures of economic power and promoting collectivism of fundamentally different nature. ${ }^{4}$ It is misleading to view business associations a

Power imbalances in capitalist society, according to Offe and Wiesenthal, generate an Capital trical logic of collective action between capital and labour organisations. associations bations correspond to a single logic (i.e., 'monological') as class-specific 'willingness to these authors because they are based on collective identity and on the 'willingness to act' 
counterpart pluralist pressure groups to union, principally because employers have differential access to power (Offe and Wiesenthal, 1980; Moran, 1983; Lash and Urry, 1984). Thus, whereas labour must organise to gain influence, business still possesses 1984). Thus, whereas labour must organise to gain influence, business still possesses
economic decision-making power without formally organising into collectives. Business organisation may augment the power of employers, but their power does not originate with organisation per se. However, as later sections of this article suggest, such theories require some modification.

Examining the structural division between industrial relations and trade interests, research already referred to has noted the inertia of many employer unions even on industrial relations matters (Brosnan, Walsh and Rowe, 1985a). While such findings have highlighted the inactivity of employer unions, the research focused only on industria relations behaviour, not on the processes of policy-making in business organisation. The main concern here was with the frequency of organisational involvement and membership participation (Brosnan, Walsh and Rose, 1985b). These findings suggested that participation across a sub-strata of state-sponsored employer 'collectives' was in general negligible. This point provides a further angle on the limitations of organisations of business.

Despite the existence of state-created representative groups, such research indicates that industrial relations was either coordinated at a centralised level (by regional or peak associations), or that specific industrial relations practices were increasingly handled at the enterprise, company or industry level through collective bargaining. The evidence of widespread disuse of these bodies by employers indicates that employers have made other choices over the appropriate organisational location of industrial relations responsibilities (Taylor and Greenslade, 1986; Brosnan and Walsh, 1986). These findings, then, provide no evidence that business associations are inactive in their internal politics, but that som formal organisation consisting of state registered employer unions at the micro-level are largely incidental to the political development of employer organisations.

\section{Initiatives toward consolidation and centralism at the peak employers} level

In response to the erosion of state-directed compulsory arbitration since the late 1960s, and then the economic crises affecting New Zealand after 1975 (OECD, 1985), employer associations moved to consolidate their policy-making networks. This entailed greater centralisation of business politics. These steps toward employer unity rested on organisational linkages and formal consultative arrangements. The first majo reorganisation in response to the growth of second tier bargaining was the 1971 restructuring of the Employer's Federation, described by Rudman, which in addition to consolidating the 11 provincial districts into 4 regional associations, also incorporated representatives from wider industry sector bodies, the Manufacturers' Federation, the Federated Farmers and the Association of Chambers of Commerce into the National Executive of the peak Federation. This reorganisation, according to Rudman, was due to employer 'disenchantment with the existing institutions' with the main initiative behind this reorganisation coming 'largely from employers' outside the Federation itself, chiefly from the Manufacturers Federation (Rudman, 1974, p. 72).

membership (Offe and Wiesenthal, 1980). Offe and Wiesenthal's distinction is founded on voluntarist criteria and the ability to obstruct the other party, rather than on contro within the labour process, the patterns of class and labour market segmentation or organisational initiative and participation in policy-making (pro-activism). See further discussion in Lash and Urry's critique of this distinction between forms of organisational conflict (Lash and Urry, 1984, pp. 39-46).
By 1977 a second organisational linkage was established, the 'Top Tier' group, which comprised the chief executives of the main business organisations. The Top Tier body was administered by the Employers' Federation, but used rotating venues and chairpersons whose responsibility it was to initiate meetings with an agenda-setting 'issues statement' from their respective organisations. This feature was important because as a leadership coalition the Top Tier rested on consultation rather than on the generation of majority decisions. From the viewpoint of the Employers' Federation, the rationale behind the existence of the composite group was to ensure that the 'business and farming community speak with one voice wherever possible and appropriate' (NZEF, 1984/5, p) role beyond mediating inter-industryble and appropriate' (NZEF, 1984/5, p. 5). Its main role beyond mediating inter-industry conflicts was to present a common voice of business to government ministers and departments. Indeed, in 1984 this body presented a joint business manifesto on strategic economic policies to the incoming Lange government within hours of its electoral win. 5 Soon after the election of the Labour Government, the Top Tier group was able to assemble a common stance on taxation policy (including
broad support for the Goods and Services Tax), superannuation and oad support for the Goods and Services Tax), superannuation and social welfare.

The 1984 Economic Summit Conference called by the Lange Government to promote 'unity and cooperation' between government, business, labour and community groups over economic problems, saw a further augmentation of business calls for unity. While the Summit was largely a public relations exercise, employers organised a business caucus to arrange speakers and maintain discipline (Interview, NZEF, 29/1/1986). Moreover the Summit provided a further forum in which business invel 29/1/1986). Moreover, the Summit provided a further forum in which business involvement in formal policy discussions continued to evolve. Consistent with these emerging attempts to construct employer unity but also out of concern over the growing influence of the Business Roundtable, the Employers' Federation in 1986 reorganised its leadership structure to combine its main industrial relations policy body (the National Executive) with the General Council to which the 4 regional and some 60 trade associations belong. Greater influence was also given to the full-time executive staff of the Federation, in that previous Director's Committee (with 5 Fe executive staff of the Federation, in that the previous Director's Committee (with 5 Federal Directors and 4 regional division officers) was upgraded to become the overall management committee of the organisation. This was intended to assist with greater forward planning, the development of a pro-active strategy and to allow the Federation to "gear up for the next period" (Interview, NZEF, 28/1/1986).

These changes were not purely organisational re-alignments. The policy networks of the various business organisations were increasingly intertwined. In particular the interna policy networks of the sectoral business organisations were increasingly integrated at the leadership level into the peak industrial relations organisation of business. Within this context, the policy interests of the peak employer body began to expand from a narrow, reactive industrial relations preoccupation to a broader set of policy concerns. This did not mean that the level and determination of wages was displaced as a paramount issue. On the contrary, as pressures toward centralisation continued, the organisation began to

The Top Tier group's policy submission to the Prime Minister elect consisted of 7 'principal objectives of economic recovery', including: increased employment, sustained growth, external competitiveness, investment and productivity, natural resource development, removing barriers to change and growth, and a pattern of income and wealth distribution that 'encourages initiative and effort'. The group identified 8 policy 'tools to achieve the objectives'. In addition to monetary, fiscal and taxation policies, they advocated a floating exchange rate, substantial reform of the wage bargaining system and a 'controlled' prices and incomes policy. The group urged government to adopt medium-term planning, encourage economic res group urged provide industry assistance, while reducing the size of the public sector. Employer, NO. 88, Aug 1984, pp. 4-5). In the first few years Government, the Lange Ministry had implemented a range of these police Labour others (e.g. monetary policy, the deficit, wage policy and labour me policies, although proved more difficult to adjust. 
conceive industrial relations in a wider context with more emphasis on the principles of policy-making, agenda-setting and the relationship between co-existing policies.

From the mid-1970s, the Employers' Federation systematically re-conceptualised its approach toward serving the interests of individual employers and business at large. The leadership of the Federation (and especially the professional staff) were of the view that they could not adequately represent employer interests as a central organisation if they remained committed only to traditional concerns. Instead, they saw it as their role to extend significantly the range of strategic policy initiatives undertaken by the . Wage outcomes and tactical wage policies remained the fundamental substantive issues of the employers' central body, but increasingly greater attention was directed to the system of wage settlement, enterprise bargaining and labour market deregulation. Moreover, these concerns were broadened by the development of a series of secondary and supplementary policies.

Centralist tendencies in business associations under the fourth Labour Government

The extension of its policy-making role characterised the Employers' Federation's response to recession and structural change in the New Zealand economy. It was also response to rapid and radically different changes in government economic policy after the Muldoon Government. These changes also affected the general relationship between business and government, especially as the influence of overseas and export-oriented sectors of business rose, and under Treasury's direction policy-making within government itself became increasingly centralised. In particular the apparent ineffectiveness of traditional protectionist and specific interest lobbying as a policy tactic caused both initia frustration and then experimentation as various domestic business organisations began to consider different ways of having policy input. The previous pattern of policy advocacy in both the Employers' Federation and Manufacturers' Federation had been characterised by political "closure" in that particularistic interests and their own internal policy processes had largely influenced policy formation. The activities of these organisations and their policy agendas were discrete and limited to the technical concerns of their small-medium sized members. Lobbying and pressure on government had been relied on as the main forms of policy advocacy (cf. Coleman, 1985 and 1988 on policy activities in Canadian business associations)

After 1984 all the major business associations were increasingly required to participate in a much more volatile pattern of intermediation between various employer groups an the state. Under such circumstances, the peak Federations attempted to coordinate the various business associations into interest coalitions by fusing the policy processes hierarchically at the leadership level. Between 1987-8 discussions over multiple organisational mergers were conducted, initially involving the manufacturers, retailers, Chambers of Commerce. A more serious proposal was raised in 1988 involving a merge of the Employers' Federation with the Manufacturers and the Chamber of Commerce. Although by 1988 these mergers had not been accomplished due to organisationa conservatism and sectoral tensions, these inter-organisational development provide further evidence of centralist tendencies at the leadership level.

This centralisation response was not a policy preference for corporatism as a means of arriving at policy solutions during times of recession. Instead, it was a structural response from organisations representing major economic interests toward securing greate participation within the state in a process of negotiated policy-making. By the mid 1980s business interests were more concerned with agenda-setting and the main directions of policy rather than with details of particular and fragmented policies.

At one level it may appear that this situation is paradoxical if not ironic. On the one hand, the traditional access of specialist business associations to government agencies over direct lobbying for particularistic interests was, for some, increasingly impeded. On the other hand, the leadership of the main agencies of business (executives of employer and trade bodies along with the influential Roundtable 'knights') began to seek and gain greater trade bodies along with the influential Roundtable 'knights') began to seek and gain greater
opportunity for participation inside the forums of policy-making within the state. Yet, as parochial and protectionist lobbying became less rewarding and important as a means of interest advocacy for some sectors of industry, business organisations took more seriously the processes of policy-making and their involvement in shaping policy frameworks and expended greater energy on policy development. This emerging trend was only partly a political response to the inom political response to the incremental strategies of trade unions to widen the bargaining agenda. It was much more due to changed forms of policy negotiation between business and government, to Treasury's dominance in state policy-making, and to the leadership within various business associations assuming a more independent strategic role based on longer-term planning and policy research related to domestic and international trends.

\section{Business responses to uncertainty over government policy interventions}

The degree of arbitrary and unpredictable government intervention in the economy over the 1970s and 1980s stimulated greater centralisation throughout business associations. Business influence over central government economic policy was more pressing as the economic recession continued and government policies fluctuated from protection to deregulation and 'market' exposure. The earlier sectoral employer access to specific economic agencies of the state was increasingly frustrated. With increasing zeal the state responded to processes of economic restructuring by introducing market-oriented policies as the principal means of adjustment. Those state agencies captured in the past by particular business interests, such as the Department of Trade and Industry, were intilly marginalised in the formation of economic policy and then 'tranformed' as policy advocates to refle for

(ocates to reflect government-Treasury thinking (see Dept. of Trade and Industry, 1987).

Moreover, arbitrary government interventions over national incomes policies encouraged the Employers' Federation to engineer greater leadership autonomy of decisionmaking within its own organisational structure. Employer representatives felt better able to participate in processes of intermediation with the state when their policy-making processes were centralised and formalised. Such centralisation, they considered, allowed for both clearly defined common policies and agreed policies to emerge within a confederation representing diverse business interests. Federation staff attempted to use such bureaucratic means in order to enhance the authority of the peak body in negotiations with the state.

Thus, although the Employers' Federation rejected tripartite decision-making on wages policy, it nonetheless proposed a common interest policy by advocating bi-lateral consulatation with government on the national framework for wage determination (NZEF, Aug 1985, pp. 7-8). Centralisation, internal agreement and policy-making authority became instrumental in facilitating closer formal links between representatives of the peak business organisation and the state. This incremental centralisation of policy-making also meant that the leadership of the peak employer body had to establish a credible position policy 'frontrunner' for business. To this progresively involved in wider and auxillary policy negolatons wite progressively involved in wider and auxillary policy negotiations with a series of other departments of state. Whereas previously this employer body had liaised exclusively with the Department of Labour on particular wage and labour issues, regular liaison became the norm with many departments after the mid-1970s, including: Education, Justice, Women's Affairs, Trade and Industry, Finance and Transport. 
The significance of representational politics for business

Attempts to fuse the policy processes of the various business organisations also grew out of the internal politics of business, especially over calls from the leaders of big business for the promotion of policy directions at both the centralised level and through ad hoc business councils. The establishment of the Business Roundtable represented a strategic initiative from big business to generate a more substantial policy input over economic issues. As a parallel and partly competitive organisational initiative from big business, this stimulated the existing peak employers' organisation to consider wider policy areas which intersected particularly with the interests of big business and the existing trade associations. Accordingly, many leaders from a range of other business organisations believed that 'competition' between these rival bodies over which was seen as the policy frontrunner and principal voice of business, effectively propelled the Employers' Federation into other substantive but non-wage policy areas. For the Federation, though, in contrast to its previous role, this effectively meant that the peak body increasingly began to formulate policies that were less tied to the immediate concerns of medium to small employers.

In addition to organisational jockeying to monopolise business representation, the trend toward greater mediation between business and the state based on a strategy of preemptive policy formulation was also a consequence of developments taking place within the leadership dynamics of business associations. The formal management of employer and trade associations (at the national or regional level) remained with the elected representatives or membership, but increasingly policy development and advocacy at the central level was determined by appointed officers within a policy secretariat. This trend was evident too in the Business Roundtable, which had appointed Kerr as its executive director to fulfil precisely this policy role. Hence, rather than being limited to mere administration, full-time officials in business organisation became increasingly responsible for policy formation and associated research. Appointed officials had generally assumed control over the policy process within their respective organisations and as a result had acquired considerable discretion in determining existing and future policy directions.

A further significant development involved in these leadership trends was the rise of a group of new organisational technocrats into key positions within most of the major business organisations. In the main, these technocrats were young professionals who saw business associations as providing career paths for the up-and-coming. Their appointments often disturbed a prevailing complacency that considered executive positions as pre-retirement sinecures for the deserving. Nonetheless, appointed officers with specialist professional skills were engaged on employment contracts which could be terminated at short notice by a management committee of elected officials. Hence, the performance and policy preferences of these new technocrats could be regularly judged according to their organisational 'fit'.

As policy 'experts', in-house consultatnts or managerial specialists, these executive officers approached policy matters from an initiative-oriented perspective that stressed realisable goals and achievements. Often these officers routinely allowed a greater role for consultation and feedback from the general employer membership. Unlike many of their organisational predecessors who attempted to ignore or suppress many contentious policy issues (e.g. tariffs), the new technocrates typically raised these issues for policy debate in order that business groups could 'smarten up' their performance and steal the policy terrain from government or labour representatives. Their contribution to the politics of business was both to assist in the revitalisation of associational interests, and to demonstrate that such organisations could generate a 'willingness to act' and be pro-active on behalf of represented interests (cf. Offe and Wiesenthal, 1980).

\section{Conclusion}

The structure of the economy as well as the differential impact of changes in the levels of economic activity had generally imposed real limits on the capacity for centralisatio within business organisation. In New Zealand, however, a series of political and economic conditions forced employers to increasingly reassess their organisationa effectiveness. Over recent years, the main characteristic of the political development business associations in New Zealand has been the emergence of significant modificit of in organisational policy-making. These changes have been most evident in the policy processes of business organisations, the formation and development of specific policies, the concern to broaden the content and range of policy advocacy, and the attempts to the concern to broaden the content and range of
maintain policy input into state decision-making.

In part, these changes have been encouraged by some significant organisational restructuring among the organisations representing business. Historically business has always required at least some form of minimal organisational structure to represent their interests. However, although the arbitration system required employers to unify as industry groups for specialised industrial relations purposes, in the present economic crisis business a business associations have developed strong centralist tendencies as a means of politica and economic adjustment. Thus, despite the observed trend towards 'inactivity' in employer unions at the lower level of business organisation, business generally has promoted a political restructuring at the upper echelons of its representational forms.

The principal effect of these policy changes and moves toward organisational restructuring has led to a greater integration of the representative organisations of business into the policy processes of the state. This has occurred in conjunction with a decline in the importance of direct lobbying over particularistic interests. The policy processes an policy-thinking of the state, thus, assumed considerably greater importance to business associations in the political environment. Moreover in recoonition of this business leadership of various business associations began to adopt more independent position policy matters, tied less to the immediate concerns of the membership than to medium erm strategic directions. As the state chose to adopt market mechis to mediumerm state chose to adopt market mechanisms to achieve economic restructuring, policy negotiations with the state increasingly tended to move away from clientelism and sectoral bargaining to a more centralised and generalised interchange involving wider topics of concern.

These developments represented not an exercise in creating a corporatist mode of policy-making, but a development in the political organisation of business designed to realign the patterns of penetration between business and the state. Mediation with the state appeared to be the most significant catalyst of employer unity at the level of policy development. In this process collective organisation proved important to business not so much in terms of obstructing other groups (as Offe, 1981 maintained) but in terms of policy input and agenda-setting. In the past the main form of mediation access to specific decision-making agencies of the state. By the mid-to-late 1980s business mediation with the state was characterised more by its prominent role within the processes of policy formation, its capacity to shape the parameters of debate, and the greater centralisation of involvement over a range of diverse policy concerns. In place of the previous emphasis on particular sectoral lobbying, a fusion of policies began to emerge involving the policy processes of business organisations and those of the state. Most importantly, this policy fusion corresponded in large part to the speed, impact and chosen directions of economic restructuring.

\section{References}

Atkinson, M and Coleman, W (1985) Corporatism and industrial policy. In Cawson, A (ed) Organised interests and the state Sage, London. 
Boston, J (1984) Incomes policy in New Zealand Victoria University Press, Wellington.

Boston, J (1985) Incomes policy and the 1985-1986 wage round: from non-market failure to market failure? New Zealand journal of industrial relations 10(2):65-82.

Brosnan, P, Walsh, P and Rowe, P (1985a) The inactivities of employer unions New Zealand journal of industrial relations 10(3):141-156.

Brosnan, P, Walsh, P and Rowe, P (1985b) Democracy and decision making in unions of employers. Mimeo, Victoria University, Wellington.

Brosnan, P and Walsh, P (1986) Reply to Taylor and Greenslade New Zealand journal of industrial relations 11:193-195.

Coleman, W (1985) Analysing the associative action of business: policy advocacy and policy participation Canadian public administration 28(3):413-433.

Department of Labour (1985) Industrial relations: a framework for review (2 vols) Wellington.

Department of Labour (1986) Annual report Wellington.

Department of Trade and Industry (1987) Corporate plan Wellington.

Dufty, F (1984) Employer associations in Australia. In Windmuller, J and Gladstone, A (eds) Employer associations and industrial relations Clarendon, Oxford.

Economic Summit Conference (1984) Proceedings and conference papers (2 vols) Parliament House, Wellington.

Grant, W (1983) Representing capital. In King, R (ed) Capital and politics Routledge and Kegan Paul, London.

Howells, J, Woods, N and Young, F (eds) (1974) Labour and industrial relations in New. Zealand Pitman, Carlton.

Lash, S and Urry, J (1984) The new Marxism of collective action: a critical analysis Sociology 18(1):33-50.

Moran, M (1983) Power, policy and the City of London. In King, R (ed) Capital and politics Routledge and Kegan Paul, London.

New Zealand Business Roundtable (1987) Freedom in employment Wellington.

New Zealand Employers' Federation (1984/5) Annual report 1984/5 Wellington.

New Zealand Manufacturers' Federation (1985) Buying guide and directory Auckland.

Offe, C and Wiesenthal, H (1980) Two logics of collective action: theoretical notes on social class and organisational form. In Zeitlin, M (ed) Political power and social theory (1) Greenwich.
Offe, C (1981) The attribution of public status to interest groups: observations on the West German case. In Berger, S (ed) Organizing interests in Western Europe Cambridge, London.

OECD (1985) Economic Surveys: New Zealand Paris.

Plowman, D (1980) Employer associations: challenges and responses. In Ford, G, Hearn, J and Lansbury, R (eds) Australian labour relations: readings Macmillan, Melbourne.

Plowman, D (1988) Employer associations and industrial reactivity Labour and industry 1(2):287-305.

Robinson, A (1978) The role of pressure groups in New Zealand. In Levine, S (ed) Politics in New Zealand George Allen and Unwin, Sydney.

Roth, H (1978) The historical framework. In Deeks, J, Farmer, J, Roth, H and Scott, G Industrial relations in New Zealand Methuen, Wellington.

Rudman, R (1974) Employer organisations: their development and role in industrial relations. In Howells, J, Woods, $\mathrm{N}$ and Young, $\mathrm{F}$ (eds) Labour and industrial relations in New Zealand Pitman, Carlton.

Taylor, R and Greenslade, B (1986) The activity of employer unions in perspective New Zealand journal of industrial relations 11:191-192.

Tsokhas, K (1984) A class apart? Businessmen and Australian politics 1960-1980 Oxford University Press, Melbourne.

Vowles, J (1985) Business and labour: major organised interests in the political economy of New Zealand. In Gold, $\mathrm{H}$ (ed) New Zealand politics in perspective Longman Paul, Auckland.

Windmuller, J and Gladstone, A (eds) (1984) Employer associations and industrial relations Clarendon, Oxford. 


\section{THE JOURNAL OF INDUSTRIAL RELATIONS}

The Journal of the Industrial Relations Society of Australia

Editor: Professor John Niland, The University of New South Wales

December 1988 - Volume 30 Number 4

Articles

The Relationship Between Youth and Adult Award

Wages from 1930 to 1985

Christine Short

Towards Tripartism: Industrial Relations in the Steel Industry 1978 to 1987

Diana Kelly

Equal Pay and Comparable Worth and the Australian Conciliation and Arbitration Commission Laura Bennett

Consultative Councils in Qantas and Telecom:

A Comparative Study

E. M. Davis and R. D. Lansbury

Arbitration and Bureaucracy: The New South Wales Railway Commissioners, 1892-1914

Greg Patmore

Book reviews

Published quarterly. Subscription: Australia \$32, overseas \$A45 (surface mail).

Single issues: \$A9 (including postage). Order from the

Business Manager, The Journal of Industrial Relations,

GPO Box 4479, Sydney, NSW 2001, Australia. 